\title{
Survey of Dry Antibiotics Most Commonly Used in The City of Niamey from 2015 to 2016
}

\section{Salifou Karimoune FADJIMATA ${ }^{1 *}$, Amadou Tidjani ILAGOUMA ${ }^{1}$ and BOUKARI Issiaka ${ }^{2}$}

\author{
${ }^{1}$ Materials, water and environment laboratory (MWEL), Faculty of Sciences and Technik, \\ Department of Chemistry, Abdou Moumouni University. BP 10662, Niamey (Niger)
}

\author{
2École Normale Supérieure (ENS), Department of Chemistry, Abdou Moumouni University. \\ BP 10963, Niamey (Niger)
}

\section{*Corresponding author details: Salifou Karimoune; salifoufadjimata@gmail.com}

\begin{abstract}
The aim of this study is to highlight the antibiotics most commonly used by the population and in the health centers of Niamey. This study will shed light on the types of antibiotics sold in pharmacies and on the streets. Achieving this objective required the use of a prospective survey method and as a survey technique, four survey questionnaires were drawn up on the antibiotics used and knowledge of street drugs including: survey questionnaire for officials of the Ministry of Public Health and the population, survey questionnaire for pharmacists and pharmacy vendors, questionnaire survey for health workers located in hospitals and survey questionnaire for street vendors. The results of the survey reveal that the antibiotics most commonly prescribed in health centers and sold in the city of Niamey are five in number: amoxicillin, ampicillin, cloxacillin; ciprofloxacin and metronidazole. Thirty percent of those persons surveyed are aware of this scourge and consume it because of the inexpensive price, the ease of obtaining it and these persons believe that they act quickly and effectively on health. So, it would be preferable to think of remedying the problem by sensitizing the population awareness on the health consequences and apparently only very large financial actions could wipe out the sale of Street Medicines which is only gaining ground.
\end{abstract}

Keywords: Antibiotics; health centers; pharmacies; street vendors; Niamey

\section{INTRODUCTION}

Nowadays, more and more people are flocking to illicit markets to buy drugs at lower cost from street vendors [1] [2]. Thus, informal markets are developing more and more because of the inexpensive nature of products. These street drugs have several origins [2], [3]. The imports of these drugs come mainly from the informal sector and are introduced into Niger fraudulently and in violation of the regulations in force [3]-[5]. The informal drug network has grown in Niger with the advent of a multiparty system from 1991 and the lifting of the ONPPC monopoly in 1997 [6]. Despite the existence of legislation which specifies the pharmacist's monopoly in the field. drug distribution, the illicit drug distribution circuit has developed in a diffuse manner in all regions of Niger, by the proliferation of a multitude of street vendors, most often from unemployed youth [2], [4], [7]. The importation of medicines into Niger is subject to prior authorization from the Ministry of Public Health. Medicines include antibiotics, any chemical or synthetic substance that is capable of destroying or blocking the growth of bacteria. They are then involved in the treatment of infectious and bacterial diseases [8], [9]. Today, this drug supply has become not only a threat to the health of the population but also to the economy and security of our country [10]-[13]. The consumption of counterfeit antibiotics results in pulmonary and renal problems in the elderly (Nephrology department at Lamordé Hospital), neurological, hematological, hepatic, allergic problems linked to their toxicity and resistance [12], [14]. WHO estimates that:
- $65 \%$ of fake medicines come from developing countries, - $25 \%$ come from industrialized countries and

- $10 \%$ of non-specific sources [5], [15].

\section{MATERIALS AND METHOD}

This study was carried out using a survey sheet containing a few questions.

\section{Population}

The population is represented by the antibiotics (from pharmacies and street vendors) most commonly sold in the Urban Community of Niamey and used in hospitals and health centers (HNN, HNL, CHR and MIG) [14], [16]-[18].

\section{Sampling and Size}

Our sample is the genesis of:

- Antibiotics prescribed by health workers;

- Antibiotics most commonly used in health centers (HNN, HNL, CHR Poudrière and MIG)

- Antibiotics sold in pharmacies;

- Antibiotics sold by itinerants.

The prospective survey

This study was carried out using four (4) survey sheets:

- A survey form including questionnaires sent to Ministry of Public Health and the population;

- A survey form including questionnaires sent to health workers located in hospitals; 
- A survey form including questionnaires addressed to pharmacists and pharmacy sellers;

- An investigation file including questionnaires addressed to street vendors.

\section{Methodology}

The investigation consists first of all in bringing out the most commonly used antibiotics in the city of Niamey. Then do a visual examination for the drugs used by the population. After that, note the different characteristics which are:

- Form of the drug

- Description of the organoleptic characters

- Weight of the drug

- Medication leaflet

- Packaging

- Assay method

- Storage

- Manufacturers

- Lot number

- Date of manufacture

- Expiry date

- Number of tablets or capsules

- Price of the brochure

Finally, to bring out the advantages and disadvantages of each.

\section{RESULTS AND DISCUSSION}

\section{Visual examination results}

During this examination, two types of Antibiotics were noticed:

- Capsules (Figure 1),

- Tablets (Figure 2).

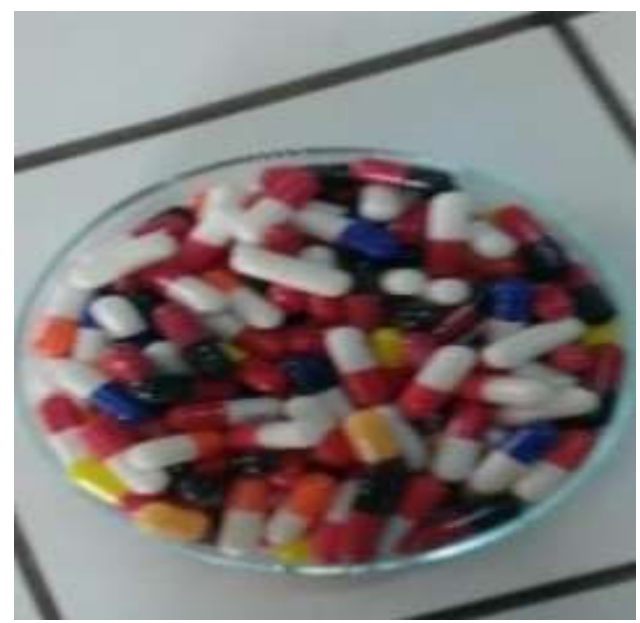

FIGURE 1: Antibiotics Capsules

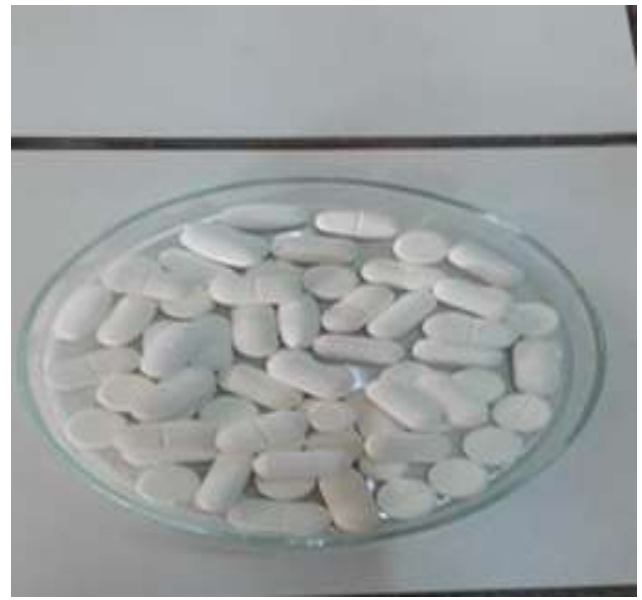

FIGURE 2: Antibiotics Tablets
Presentation of the prospective survey results

The results of the survey reveal that the antibiotics most commonly prescribed in health centers and sold in the city of Niamey are five (5) in order of importance including:

- $60 \%$ are from the ßeta-lactam family

(Amoxicillin, Ampicillin, Cloxacillin);

- $20 \%$ of the Fluoro-quinolones family (Ciprofloxacin);

- $20 \%$ of the imidazole family (Metronidazol).

\section{The Beta-lactam family}

The antibiotics of the $\beta$ eta-lactam family found are in order of importance: Amoxicillin, Ampicillin and Cloxacillin.

\section{$>$ Amoxicillin}

It is the first antibiotic (figure 3) which is most used. It is part of the family of beta lactams, the group of penams and the subgroup of Aminopenicillins. Its crude chemical formula is $\mathrm{C}_{16} \mathrm{H}_{19} \mathrm{~N}_{3} \mathrm{O}_{5} \mathrm{~S}$ with a molecular weight of 365.4 gmol-1 $^{-1}$. Its IUPAC name is (2S,5R,6R)-6-[[(2R)-2-Amino(4hydroxyphenyl) acetyl] amino]3,3-dimethyl-7-oxo-4-thia1-azabicyclo [3.2.0] heptane-2-carboxylic acid [19, p. 633]. There are two types of Amoxicillin:

- Amoxicillin Sodium which the chemical formula is $\mathrm{C}_{16} \mathrm{H}_{18} \mathrm{~N}_{3} \mathrm{NaO}_{5} \mathrm{~S}$ with a molecular weight of 387.4 gmol- $^{-1}$;

- Amoxicillin Trihydrate whose chemical formula is $\mathrm{C}_{16} \mathrm{H}_{19} \mathrm{~N}_{3} \mathrm{O}_{5} \mathrm{~S}, 3 \mathrm{H}_{2} \mathrm{O}$ with a molecular weight of 419.4 gmol-1. $^{-1}$.

Amoxicillin is generally used in respiratory infections [3], [20].<smiles>CC1(C)S[C@@H]2[C@@H](NC(=O)[C@@H](N)c3ccc(O)cc3)C(=O)N2[C@H]1C(=O)O</smiles>

FIGURE 3: Chemical structure of amoxicillin [20]

\section{$>$ Ampicillin}

The second antibiotic used is ampicillin (figure 4). Its crude chemical formula is $\mathrm{C}_{16} \mathrm{H}_{19} \mathrm{~N}_{3} \mathrm{O}_{4} \mathrm{~S}$ and its molecular weight is 349.4 [19, p. 635]. Its IUPAC name is $(2 \mathrm{~S}, 5 \mathrm{R}, 6 \mathrm{R})-6-$ ([(2R)-2-amino-2-phenylacetyl] amino) -3,3-dimethyl-7oxo-4-thia-1-azabicyclo [3.2.0] heptane-2- carboxylic acid [2], [19, p. 635]. It is part of the family of beta lactams, the group of penams and the subgroup of Aminopenicillins. It is indicated for the treatment of bacterial infections caused by susceptible germs. It is broad spectrum and acts on BGP (Gram-positive bacteria) and certain BGN (Gram-negative bacteria) [21], [22]. Ampicillin belongs to the class of medications called antibiotics, or more precisely penicillin [19, p. 635], [21], [23]. It is used alone or in combination with other antibiotics to treat and prevent infections which caused by certain types of bacteria. This medicine works by killing bacteria or by preventing their excessive proliferation [21], [22]. There are two types of Ampicillin:

- Ampicillin Sodium: its formula is $\mathrm{C}_{16} \mathrm{H}_{18} \mathrm{~N}_{3} \mathrm{NaO}_{4} \mathrm{~S}$ and its molecular weight is $371.4 \mathrm{gmol}^{-1}$;

- Ampicillin Trihydrate: its formula is $\mathrm{C}_{16} \mathrm{H}_{19} \mathrm{~N}_{3} \mathrm{O}_{4} \mathrm{~S}, 3 \mathrm{H}_{2} \mathrm{O}$ and its molecular weight is 403.4 gmol-1 $^{-1}[19$, p. 635]. 
<smiles>CC1(C)S[C@@H]2[C@H](NC(=O)[C@@H](N)c3ccccc3)C(=O)N2[C@H]1C(=O)O</smiles>

FIGURE 4: Chemical structure of Ampicillin [21]

\section{$>$ Cloxacillin}

The last antibiotic used in the family of beta lactam is named cloxacillin (figure 5). Its crude chemical formula is $\mathrm{C}_{19} \mathrm{H}_{18} \mathrm{ClN}_{3} \mathrm{O}_{5} \mathrm{~S}$ and its molecular weight is $435.9 \mathrm{gmol}^{-1}$ [19, p. 840], [24]. It is part of the family of beta lactams, of the group of penams and of the subgroup of Penicillin M. This family is particularly effective against staphylococci, germs capable of inactivating simple penicillin. It is used in the treatment of skin infections caused by staphylococci or streptococci [22].

There is cloxacillin Sodium which chemical formula $\mathrm{C}_{19} \mathrm{H}_{17} \mathrm{ClN}_{3} \mathrm{NaO}_{5} \mathrm{~S}, \mathrm{H}_{2} \mathrm{O}$ and a molecular weight of 475.9 gmol- $^{-1}$. Its IUPAC name is $(2 S, 5 R, 6 R)-6-[[[3-(2-$ Chlorophenyl)-5-methyl-4-isoxazolyl] carbonyl]-amino] 3,3-dimethyl-7-oxo-4-thia-1-azabicyclo [3.2.0] heptane-2carboxylic acid [19, p. 840].<smiles>Cc1onc(-c2ccccc2Cl)c1C(=O)NC1C(=O)N2[C@@H](C(=O)O)C(C)(C)S[C@H]12</smiles>

FIGURE 5: Chemical structure of Cloxacillin [24]

\section{The fluoro-quinolones family}

The antibiotic of the fluoro-quinolones family identified is Ciprofloxacin (figure 6). Its crude chemical formula is $\mathrm{C}_{17} \mathrm{H}_{18} \mathrm{FN}_{3} \mathrm{O}_{3}$ and its molecular weight is $331.4 \mathrm{gmol}^{-1}$. It is part of this family and of the group of fluoro-quinolones [22], [25]. Its IUPAC name is 1-Cyclopropyl-6-fluoro-4oxo-7-piperazin-1-ylquinoline-3-carboxylic acid [19, p. 808-809], [22], [26]. It is an antibacterial agent used to treat infections of the skin, sinuses, bones, lungs, abdomen, kidneys, prostate and bladder and also some sexually transmitted infections, certain forms of diarrhea, infectious origin, and typhoid fever [11], [12], [26]. There are two types of Ciprofloxacin:

- Ciprofloxacin Hydrochloride: its crude chemical formula is $\mathrm{C}_{17} \mathrm{H}_{18} \mathrm{FN}_{3} \mathrm{O}_{3}, \mathrm{HCl}, \mathrm{H}_{2} \mathrm{O}$ and its molecular weight is $385.8 \mathrm{gmol}^{-1}$.

- Ciprofloxacin Lactate: its crude chemical formula is $\mathrm{C}_{17} \mathrm{H}_{18} \mathrm{FN}_{3} \mathrm{O}_{3}, \mathrm{C}_{3} \mathrm{H}_{6} \mathrm{O}_{3}$ and its molecular weight is 421.4 gmol-1 $^{-1}$ [19, p. 808-809].<smiles>O=C(O)c1cn(C2CC2)c2cc(N3CCNCC3)c(F)cc2c1=O</smiles>

FIGURE 6: Chemical structure of Ciprofloxacin [25]

\section{The imidazole family}

The antibiotic identified in the imidazole family is Metronidazole (figure 7). Its crude chemical formula is $\mathrm{C}_{6} \mathrm{H}_{9} \mathrm{~N}_{3} \mathrm{O}_{3}$ and its molecular weight is 117.2 gmol- $^{-1}$. Its IUPAC name is 2-Methyl-5-nitroimidazole-1-ethanol [19, p. 1276-1277]. It is part of the imidazole family. Metronidazole is an Antiprotozoal, Antibacterial which It is part of the imidazole family. This product is an antibiotic and antiparasitic belonging to nitroimidazoles. It inhibits nucleic acid synthesis and is used for the treatment of infections associated with anaerobic bacteria as well as protozoa [22], [27].<smiles>Cc1ncc([N+](=O)[O-])n1CCO</smiles>

FIGURE 7: Chemical structure of Metronidazol [27]

Presentation of the characteristics of antibiotics We noted all the characteristics listed and mentioned which could be the subject of a difference between the two categories of antibiotics (those sold in pharmacies and those of itinerant sellers) and other between the two types namely tablets and capsules (Tables 1 and 2).

TABLE 1: Presentation of the characteristics of antibiotics: case of tablets

\begin{tabular}{|l|l|l|l|}
\hline Characteristics & \multicolumn{1}{|c|}{$\begin{array}{c}\text { Specialty Antibiotic } \\
\text { (Pharmacy) }\end{array}$} & \multicolumn{1}{|c|}{$\begin{array}{c}\text { Generic antibiotic } \\
\text { (Pharmacy) }\end{array}$} & \multicolumn{1}{c|}{$\begin{array}{c}\text { Generic antibiotic } \\
\text { (Street) }\end{array}$} \\
\hline Form of the drug & Mentioned & Mentioned & Mentioned \\
\hline Weight of the drug & Mentioned & Mentioned & Mentioned \\
\hline Medication leaflet & Included in the box & Included in the box & Non-existent \\
\hline Packaging & in the box & Box or drug packs & drug packs, retail sale or sale by unit \\
\hline Assay method & Often described & Described on some & Not described \\
\hline Storage & Mentioned & Mentioned & Room or street temperature \\
\hline Manufacturers & Mentioned & Mentioned & Not mentioned \\
\hline Lot number & Mentioned & Mentioned & Not mentioned \\
\hline Date of manufacture & Mentioned & Mentioned & Rarely \\
\hline Expiry date & Mentioned & Mentioned & Rarely \\
\hline Number of tablets & 10,12 or 14 & 10 or 12 & 10 \\
\hline Price of the brochure & Mentioned on the box & 1000 FCFA on average & 200 FCFA on average \\
\hline
\end{tabular}


TABLE 2: Presentation of the characteristics of antibiotics: case of capsules

\begin{tabular}{|l|l|l|l|}
\hline Characteristics & \multicolumn{1}{|c|}{$\begin{array}{c}\text { Specialty Antibiotic } \\
\text { (Pharmacy) }\end{array}$} & \multicolumn{1}{|c|}{$\begin{array}{c}\text { Generic antibiotic } \\
\text { (Pharmacy) }\end{array}$} & \multicolumn{1}{c|}{$\begin{array}{c}\text { Generic antibiotic } \\
\text { (Street) }\end{array}$} \\
\hline Form of the drug & Mentioned & Mentioned & Mentioned \\
\hline Weight of the drug & Mentioned & Mentioned & Mentioned \\
\hline Medication leaflet & Included in the box & Included in the box & Non-existent \\
\hline Packaging & In box & In Box or drug packs & drug packs, retail sale or sale by unit \\
\hline Assay method & Described on some & Described on some & Not described \\
\hline Storage & Mentioned & Mentioned & Room or street temperature \\
\hline Manufacturers & Mentioned & Mentioned & Not mentioned \\
\hline Lot number & Mentioned & Mentioned & Not mentioned \\
\hline Date of manufacture & Mentioned & Mentioned & Rarely mentioned \\
\hline Expiry date & Mentioned & Mentioned & Rarely mentioned \\
\hline Number of capsules tablets & 10 or 12 & 10 or 12 & 10 \\
\hline Price of the brochure & Mentioned on the box & 600 FCFA on average & 400 FCFA on average \\
\hline
\end{tabular}

According to the two (2) tables above, the antibiotics of pharmacies are sold to the customer only after presentation of his prescription especially the specialties while those of the street are sold at the request of the customer.

\section{CONCLUSION}

Antibiotics of Reference (specialty) and generic from pharmacies have all the characteristics include in their box but antibiotics for the street vendors have only the form of the drug and the weights which are mentioned on the brochures. The others characteristics are often or rarely mentioned. Tablets (generic) from pharmacies are more expensive than capsules; on the other hand, the tablets from street vendors are cheaper than the capsules.

Almost a third of those surveyed on street drugs aware of this scourge and consume it; including some health workers also saying that these drugs are not only cheaper and easy to obtain but also that they work quickly and effectively on health.

So, it would be better to think of remedying the problem by raising public awareness of the health consequences and apparently only very large financial actions could wipe out the sale of Street Medicines which is only gaining ground.

\section{ACKNOWLEDGMENT}

- The authors are very thankful to:

- Niamey National Hospital (HNN);

- Amirou Garga Hospital of Lamordé (HNL);

- Poudrière regional Hospital Center (CHR);

- Maternity Issaka Gazobi (MIG);

- Pharmacists and pharmacy vendors;

- Street vendors.

\section{REFERENCES}

[1] OUEDRAGO SAMIRATOU, «Les Médicaments de la rue en zone défavorisée d'Ouagadougou (Burkina Faso) », Université Mohamed de Rabat, 2008.

[2] DIALLO MOUSTAPHA, «Contribution à l'évaluation du marché illicite du médicament au Niger à partir des statistiques douanières d'importation des médicaments, réactifs de Laboratoire et consommables médicaux de 1999 à 2003 ", Université Abdou Moumouni, FSS, 2005.
[3] M. HAMEL VINCENT, «La vente illicite de médicaments dans les pays en développement: analyse de l'émergence d'un itinéraire thérapeutique à part entière, situé en parallèle du recours classique aux structures officielles de santé », Université de Lyon, 2006.

[4] [4] JOCELYNE SAMBIRA, « Médicaments contrefaits : un problème en Afrique, L'Ampleur des profits et la légèreté des peines alimentent la criminalité », p. 35 , 2013.

[5] «Les faux médicaments durs à détecter », Le Figaro, 2013

[6] ORDONNANCE portant législation pharmaceutique. p. 52.

[7] HADIZA MOUSSA ABDALLAH, "La Pharmacie par terre au Niger: une alternative à l'échec de la politique pharmaceutique nationale. Etude de cas de la Commune Niamey III », Université d'Ouagadougou, 2000.

[8] J.W. BENNET, what is an antibiotic. 2005.

[9] "Antibiotique, Classification», https://fr.wikipedia.org/wiki/Antibiotique, Classification, 2016.

[10] «Les Médicaments contrefaits : un problème de santé en Afrique », 2013.

[11] «Santé », http://afssaps.santé.fr/htm.

[12] SAOUDOGO HAMADO, « Etudes des risques de santé liés à l'utilisation des médicaments vendus sur le marché informel à Ouagadougou », Université d'Ouagadougou, 2003.

[13] « Le Circuit informel des médicaments à Yaoundé et à Niamey : Etude de la population de vendeurs et de la qualité des médicaments distribués », 2007.

[14] HNL, « Service Surveillant ». 2015. 
[15] OMS, «STRATEGIE PHARMACEUTIQUE DE L'OMS : Cadre d'action pour les médicaments essentiels et politique pharmaceutiques 2000-2003 », Genève, 2000.

[16] HNN, « Service Surveillant ». 2015.

[17] CHR Poudrière, Niamey, «Service de l’Epidémiologie ». 2015.

[18] MIG, Niamey, « Service de DRH ». 2015.

[19] Anthony C Moffat, M David Osselton and Brian Widdop, CLARKE'S Analysis of Drugs and poisons, Third Edition., vol. Volume 2. 2003.

$[20]$ « Amoxicilline », https://fr.wikipedia.org/wiki/Amoxicilline.

[21] « Ampicilline», https://fr.wikipedia.org/wiki/Ampicilline,.
[22] ENSP, Niamey, «Bactériologie : les Antibiotiques, ENSP de Niamey. » 2004.

[23] SIDIBE MOUSSA, «Contrôle analytique des formes pharmaceutiques comprimés et gélules des médicaments à base d'amoxicilline et d'Ampicilline vendus sur les marchés de Conakry », 2006.

[24] « Cloxacilline », https://upload.wikimedia.org/wikipedia/commons/t humb/2/25/220px-Cloxacillin.svg.png.

[25] « Ciprofloxacine», https://fr.wikipedia.org/wiki/Ciprofloxacine.

[26] « Ciprofloxacine», (https://ressourcessante.salutbonjour.ca/drug/getdr ug/cipro).

[27] « Métronidazole», https://fr.wikipedia.org/wiki/Métronidazole. 